\title{
ЛИНГВОПРАГМАТИЧЕСКАЯ СПЕЦИФИКА ПРЕФИКСАЛЬНЫХ ГЛАГОЛЬНЫХ ДЕРИВАТОВ В РУССКОЯЗЫЧНЫХ МЕДИЙНОМ И ФОРУМНОМ ДИСКУРСАХ
}

\author{
ЛАРИСА В. РАЦИБУРСКАЯ \\ Национальный исследовательский Нижегородский государственный университет \\ имени Н.И. Лобачевского \\ Институт филологии и журналистики \\ Кафедра современного русского языка и общего языкознания \\ ул. Большая Покровская, д. 37, 603000, г. Нижний Новгород, Россия \\ e-mail: racib@yandex.ru \\ ЕЛЕНА В. ЩЕНИКОВА \\ Национальный исследовательский Нижегородский государственный университет \\ имени Н.И. Лобачевского \\ Институт филологии и журналистики \\ Кафедра современного русского языка и общего языкознания \\ ул. Большая Покровская, д. 37, 603000, г. Нижний Новгород, Россия \\ e-mail: shen1@yandex.ru \\ (получено 17.08.2017; принято 27.09.2017)
}

\section{Abstract \\ Linguo-pragmatic features of prefixal derivatives of verbs in Russian- -language media and Internet-forum discourse}

The paper deals with non-usual prefixal verbs represented in the Russian-language segments of media and Internet-forum discourse. The word-building units are analyzed in the semantic, stylistic and functional-pragmatic aspects: they are divided into 
semantic groups; the changes of meanings of the prefixes are presented in comparison with the situation of the end of the 20th century; stylistic devices realized in the process of creation and usage of prefixal verbs are described; their functional loading is analyzed.

\section{Key words}

Derivational neologisms, prefixal verbs, mass media, Internet forums, expression, language play.

\section{Резюме}

Осуществляется анализ неузуальных префиксальных глаголов, представленных в русскоязычных сегментах медийного и форумного дискурсов. Словообразовательные единицы рассматриваются в семантическом, стилистическом и функционально-прагматическом аспектах: выделяются их семантические группы, отмечаются изменения значений префиксов по сравнению с ситуацией конца $\mathrm{XX}$ века; представляются стилистические приемы, реализуемые при создании и употреблении префиксальных глаголов, рассматривается их функциональная нагрузка.

\section{Ключевые слова}

Словообразовательные неологизмы, префиксальные глаголы, масс-медиа, интернет-форумы, экспрессия, языковая игра.

В условиях глобализации, виртуализации общественной жизни многократно усиливается роль СМИ и Интернета, язык которых претендует на роль общего, усредненного языка разных народов. Интерес исследователей к соответствующим типам дискурса в последние годы коррелирует с актуализацией прагмалингвистических и лингвокогнитивных исследований явлений языка и речи: «В современной лингвистике всё больше внимания уделяется лексической прагматике, предметом изучения которой являются прагматические свойства отдельного слова - прагматические компоненты в структуре его значения» ${ }^{\text {. }}$

В языке масс-медиа не только «активно реализуются системные потенции общенародного языка и наиболее полно отражается его социальная структура: язык масс-медиа интересен также в аспекте аксиологическом» ${ }^{2}$. По мнению уче-

1 Е.Б. Кузьмина. Идеологический прагматический компонент семантики слов русского языка (лексикографический аспект). «Studia Rossica Gedanensia» 2016, 3, с. 160.

2 Е.И. Коряковцева. Очерки о языке современных славянских СМИ (семантико-словообразовательный и лингвокультурологический аспекты). Siedlce: Uniwersytet PrzyrodniczoHumanistyczny w Siedlcach, 2016, c. 7. 
ных, «перерабатывая информацию и передавая её читателю, комментируя или аранжируя события, СМИ формируют моральные нормы, эстетические вкусы и оценки, выстраивают иерархию этических и эстетических ценностей, а нередко даже навязывают читателю образцы рецепции истин исторических, социально-политических, психологических и др.»³.

Интернет-форумы отличаются своей структурно-смысловой организацией. В целом каждый из них монотематичен, однако общение коммуникантов на форуме политематично, оно предполагает обратную связь и неограниченный доступ. На форумах «интернавты не только высказывают свою точку зрения, но и стараются аргументировать её» ${ }^{4}$ они «нередко создают “индуцированные неодериваты”, представляющие интерес для исследователя новых словообразовательных явлений и деривационных процессов» 5 .

В современных медийном и форумном дискурсах словообразование является эффективным инструментом для решения прагматических задач. В современную эпоху возможности словотворчества значительно расширяются, поскольку они не только отражают, но и определяют изменения в общественном и индивидуальном сознании. Деривационные процессы и отношения «отражают способы усвоения знаний и опыта с помощью актуальных для данной эпохи корневых и аффиксальных морфем, используемых для объективации новых концептов и связей» ${ }^{6}$. Анализ неодериватов медийной и форумной речи дает представление об активности и продуктивности новых словообразовательных типов, моделей, аффиксов и позволяет понять, как в языковом сознании говорящего в ходе номинации осмысливаются новые явления действительности.

В начале XXI века в разных коммуникативных сферах проявляют продуктивность префиксальные типы глаголов преимущественно с исконными русскими префиксами, что отражает тенденцию, отмеченную Е.А. Земской еще в 1980-1990-е годы ${ }^{7}$. И в частности, префиксальные глагольные дериваты составляют заметные (хотя, и не самые многочисленные) группы неузуальных слов в русскоязычных медийном и форумном дискурсах.

Высокую продуктивность проявляют типы префиксальных глаголов в текстах, представленных в центральной и региональной российской прессе ${ }^{8}$, на российских телеканалах и радиостанциях ${ }^{9}$, а также на российских интернет-форумах, относящихся к ряду тематических групп ${ }^{10}$.

3 Там же, с. 7.

4 Там же, с. 11.

5 Там же, с. 11.

6 Там же, с. 9.

7 Е.А. Земская. Активные процессы современного словопроизводства. [В:] Русский язык конияа ХХ столетия (1985-1995). Москва: Языки русской культуры, 1996, с. 90-141.

8 Газеты: «Антенна-Телесемь», «Завтра», «Комсомольская правда», «Культура», «Ленинская смена», «Литературная газета», «Селедка», «Собеседник».

9 1-й канал, Россия 1, Радио России, Вести FМ.

10 К исследованию привлечены форумы четырех тематических групп: «домашние животные», «авто», «недвижимость», «путешествия», а именно: 1) форумы любителей кошек: Форум о мейнкунах. [Online:] <http://mainecoon-forum.ru> (20.08.2017) (далее, в ссылках на 
Семантико-функциональные особенности неузуальных префиксальных глаголов отражают специфику освоения русским языковым сознанием новых реалий разных сфер действительности, а также оценку говорящими окружающих реалий.

Префиксальные глагольные дериваты как в медийном, так и в форумном дискурсе обнаруживают принадлежность к ряду семантических групп, регулярно передавая ряд смысловых оттенков.

В обоих типах дискурса распространены глаголы, которые акцентируют внимание на количественно-качественных аспектах действий/состояний (при этом значения префиксов, а также конкретные словообразовательные модели нередко оказываются субъективно-оценочными).

Заметную группу среди таких глаголов составляют слова, указывающие на степень полноты/неполноты, интенсивности действия и т.п.

В медийных текстах семантика интенсивности, избыточности, чрезмерности, многократности, всеохватности действия реализуется новообразованиями с префиксом пере-: Где-то добавила, где-то убавила, где-то передобавила, где-то недоубавила (1-й канал, 06.11.2015); Как не перепотреблять продукть (Радио России, 15.11.2016); Американць где перекупили, где перезапугали эту элиту (Россия 1, 22.11.2015). В последнем случае у префикса появляется семантика распространения (действия) на все объекты.

Для форумного дискурса префикс пере- в рассматриваемом значении не столь характерен. Семантика интенсивности, избыточности, чрезмерности,

источники текстовых примеров, сокращенно - МФ); Cat- борум. [Online:] <http://mauforum. ru> (20.08.2017) (далее сокращенно - MAУ); MaineCoon Portal. [Online:] <http://mainecoonportal.ru> (20.08.2017) (далее сокращенно - МП) - и форумы любителей собак: Моя собака CAO. [Online:] <http://dogs-forum.ru> (20.08.2017) (далее сокращенно - САОФ); Собаки Средней Азии. [Online:] <http://cao.borda.ru/.ru> (20.08.2017) (далее сокращенно - СБ); 2) форумы автовладельцев: a) Matizclub. [Online:] <http://matizclub.net> (20.08.2017) (далее сокращенно - A1); б) Матиз клуб. [Online:] <http://www.e1.ru> (20.08.2017) (далее сокращенно - A2); в) автомобильные форумы на платформе NN.RU: Девушка за рулем: для девушек и не только, Нижегородский автофорум: Для автолюбителей и автопрофессионалов. [Online:] <https://www. nn.ru/community/> (20.08.2017) (далее сокращенно - A3); 3) форумы, посвященные вопросам купли-продажи, аренды, коммунального обслуживания жилья: а) форумы о недвижимости на платформе NN.RU: Недвижимость Нижнего Новгорода - N1.RU: Форум о нижегородском рьнке недвижимости, Жалобная книга - недвижимость: Форум о недобросовестных нижегородских риэлторах, застройщиках, управляющих компаниях, Цветы ж/к, Верхнепечерская слобода пос.: форум домов, КП Аладдин: Форум для жителей коттеджного поселка, КМ Анкудиновский парк ЖК: Форум жилого комплекса, Красная Поляна ЖК: форум жилого комплекса, Квартал Европейский жк: форум жилого комплекса. [Online:] <https://www.nn.ru/community/> (20.08.2017) (далее сокращенно - Н1); б) Форум жителей коттеджного поселка Мечта. [Online:] <http://forum.tsg-mechta.ru> (20.08.2017) (сокращенно - Н2); 4) форумы любителей речных круизов: а) форум на сайте судоходной компании «Водоход» [Online:] <https:// vodohod.com/club/forum/> (20.08.2017) (далее сокращенно - ВЪ); б) Речной форум. [Online:] $<$ https://riverforum.net> (20.08.2017) (далее сокращенно - РеФ). 
многократности действия передается здесь посредством широкой группы префиксов, ни один из которых нельзя выделить как наиболее типичный:

- вы- ('интенсивно и (или) тщательно совершить действие'11): У меня два года назад в новогоднюю ночь вот так же кот выскочил, я вся обыскалась. На улиие минус сорок, праздники, а он где-то один-одинешенек, я все глаза выревела ${ }^{12}(\mathrm{CАОФ,} \mathrm{09.01.2017);}$

- за- ('интенсивно и/или в течение длительного периода времени совершать действие' - в академической Русской грамматике 1980 года данное значение у префикса не выделяется): Не отказалась бы я закруизить по Вишере! Уж очень живописна она сама (РеФ, 01.05.2017) (семантика префикса является комплексной: помимо качественно-количественного оттенка здесь просматривается оттенок начала действия);

- из-/ис- ('интенсивно совершить действие'): через сколько-то дней мне все это надоело и вернула ему наполнитель.... сколько у него радости было, весь изрылся и ископался))) (МФ, 21.01.2016);

- на- ('интенсивно совершить действие'): (...) сначала понять не могла, че народ наш дом по дороге уже обходит. А потом глядь, а чадушко развлекается, хвостиком намахивает (СБ, 02.01.2017); Тут подьехал другой кадр на Шевроле Лачетти. Начал насигналивать (А 1, 11.03.2013) (в приведенных примерах добавление словообразовательных префиксов сочетается с заменой видового суффикса: махать $\rightarrow$ намахивать, сигналить $\rightarrow$ насигналивать);

- об- ('интенсивно совершить действие' - в академической грамматике 1980 года данное значение у префикса не выделяется): Хорошо, что Bы предупредили меня о том, что упаковка другая, а то я б обвозмущцаласв (МАУ, 13.11.2014);

- om- ('полностью, окончательно совершить действие'): Да и менять (автомобиль. - Авт.) сразу после покупки, тоже трата денег по сути. Вы свои вложения не отвездили, так сказать (А1, 22.08.2016);

- пере- ('интенсивно совершить действие'): Я бы раньще тормозить начал при таком раскладе - может у чувака тормоза кончились и он полюбому на мою полосу вылезет. Лучше перетормозить ИМХО, чем ждать пока оно само уберется с дороги (А1, 13.01.2012);

- по- ('многократное (...) действие'): Дерево вроде идеально, но она жего все порасклюет и из-за этого будет плохо мььться... (МФ, 04.03.2015);

- раз-/рас- ('совершить с большой интенсивностью'): Семыч-то как разудивлялся!!! (МФ, 04.07.2015); сейчас вроде расстроились, много новых ЖК строят, а вот года 3 назад ничего кроме хрущей в продаже не было (Н1, 11.05.2017) и др.

Некоторые из указанных префиксов встречаются в медийных глаголах: Хозяйственного и работащего Александра прямо-таки выбешивало огульное раз-

\footnotetext{
11 Здесь и далее, за исключением особо оговоренных случаев, значения префиксов приводятся по академическому изданию Русская грамматика. Т. 2. Москва: Наука, 1980.

12 Здесь и далее при цитировании текстов интернет-форумов авторские орфография и пунктуация сохраняются.
} 
долбайство старшего брательника (Ленинская смена, 09.06.2016); в том числе в составе префиксально-суффиксальных формантов: Видимо, мы ещё не напотреблялись (Вести FM, 06.11.2016).

В форумном дискурсе помимо отдельных префиксов в образовании новых глаголов участвует также полипрефиксальный формант пона- со значением 'интенсивное действие, совершаемое многими субъектами' (в академической Русской грамматике 1980 г. не рассматривается): И вот представилось на секундочку, как пришёл такой простой покупатель и создал подобную тему... Вот бъ по башке то сразу понаприлетело... (МФ, 07.05.2012).

Указание именно на большое количество в форумных контекстах нередко осуществляется также за счет префикса на- с языковым значением 'накопить(ся) в определенном (курсив наш. - Авт.) количестве': Ну так и я об этом - наудовлетворяли спрос на адекватноценных котят.... (МФ, 10.11.2014); В конце видео еще кучка пластмассовых инопомоечек натюкалась (А1, 16.04.2014).

В форумном дискурсе у единиц анализируемой группы сема большого/ значительного количества периодически сочетается с отрицательной семой. В частности, это наблюдается в составе таких значений, как 'причинить ущерб': две ночи у нее оставалась ночевать, дак она меня обкормила... и отказаться неудобно, она от всей души (А2, 01.02.2014); 'с нежелательно большой длительностью совершить действие': Катририще, вы перепариваетесь... (...) вы слишком загнались по выбору, надо как то отпустить себя (МФ, 12.01.2016).

Семантика неполноты, незначительной степени интенсивности действия в обоих видах дискурса реализуется прежде все посредством префиксов недои под- (последний особенно продуктивен в СМИ): Откуда у подростков такая агрессия? Недодрались в раннем возрасте на переменах? (Радио России, 28.04.2017); чего-то там недопьлесосили (Радио России, 26.09.2016); В аудитории (Балтийского федерального университета им. И. Канта. - Авт.) обычно не увидишь патриотически настроенных студентов или аспирантов. Все уже основательно зачищено от русизма. А «недоизгнанные» патриоты из числа пробессуры или в подполье, или просто не приглашаются (Литературная газета, 24-30.03.2016, № 12); Каюсь, что сегодня почему то недощелкнул ближний свет и включил только габариты (А1, 22.09.2012); Если вы недовозвмёте летних вещей, то этого добра на теплоходе в сувенирном киоске полно (ВЬ, 19.05.2017); Нет, понятно, что санкиии, падение иен на небть и прочие попьтки наших западных «партнеров»во главе с США добиться от Кремля полной покорности кое-кого «поднагнули»...(Завтра, 2015, № 42); Сегодня власть чиновников надо подурезать (Вести FM, 16.11.2016); У нас в России интерес к шахматам как-то подзаглох (Вести FM, 11.12.2016); Сейчас телевидение там (в США. Авт.) подуспокоилось? (Вести FM, 10.08.2017); Почитал тему. Один неизвестный человек написал про неизвестную собаку о ее неизвестных примерах трусости. И многие известные стали доказывать друг другу и даже подсориваться (СБ, 02.01.2015).

Нельзя не отметить, что в обоих типах дискурса префикс недо- активно расширяет свои синтагматические возможности и, помимо глаголов, нередко присоединяется к именам. Прежде всего это имена существительные: (...) хмурые 
после московской недовесны пассажиры наконеи, ульбаются (Комсомольская правда, 16.03.2016, № 27); Мьь вас не допускаем (к соревнованиям. - Авт.), потому что вы недопилоты (Радио России, 16.08.2017); (...) гнилой недоприни датский (Вести FM, 29.08.2017); тоже в выходные недошипы (6-й сезон резине) поставил, всяко рад (А2, 13.10.2014), Да, есть такое. Какие-то недотрехместки. Там есть где развернуться, в отличии от обычных 2.2 (РеФ, 14.08.2014). Кроме того, в форумном дискурсе отмечено сочетание префикса с именами прилагательными: A т.к. у нас государство недоправовое, то никто не будет на стороне хозяина доводить дело до суда (Н1, 18.01.2017); Есть недорыжий) (котенок. - Авт.), но оочень красивыц̆) (МФ, 09.04.2015).

Реже для указания на неполноту, незначительную степень интенсивности действия используются другие префиксы:

- по-: Жаль японцы глиняные наполнители не уважают... Им лишь бы отходы поперерабатывать (МАУ, 20.05.2015); У “Грина” слабая загрузка на август и сентябрь этого года. Вот и намекают - спешите покруизить на люкстеплоходе (РеФ, 26.07.2016);

- при-: На видео, ну ладно не нравится ему за камазом ехать, так или приотпусти камаз или опереди и вправо уйди (А1, 13.10.2012);

- до-: надо взять любт по времени, чтобы они доорганизовались и доподготовились (Радио России, 16.11.2016) (в данном примере префикс до- реализует также значение 'окончить длившееся определенное время действие'). И пользователи интернет-форумов, и журналисты склонны обращать внимание на негативные аспекты окружающей действительности. Не случайно для обоих рассматриваемых типов дискурса характерны префиксальные глаголы со значением 'довести до нежелательного состояния': (...) додемонизировала Россию до такой степени (Россия 1, 26.02.2017); По этнической чисткой я не имел в виду, что их надо всех загеноцидить (Вести FM, 20.06.2017). В медийных текстах новообразования с префиксом до- могут создаваться чересступенчатым способом с пропуском ступени беспрефиксного глагола: Дотолерантничались. Еще недавно немиь рукоплескали Ангеле Меркель, демонстрирующей настолько стойкую толерантность, что ее хватило бы на весь Евросоюз... (Комсомольская правда, 12.01.2016) - префиксально-постфиксальная модель предполагает в качестве исходного слова неузуальный глагол толерантничать. Аналогичным способом создан и окказионализм дошарлились: Дошарлились. В свежем номере скандального журнала «Шарли Эбдо» выживщие франщузкие карикатуристы похихикали над утонувшим сирийским мальчиком... (Комсомольская правда, 16.09.2015). Оба неузуальных глагола обладают ярким негативно-экспрессивным потенциалом.

Особенно заметной данная группа единиц является в форумном дискурсе, где представлена моделями с разными префиксами:

- до-: Кгм, да в наших краях бри и скоттишей давно доразмножали до такой степени, что форум забит предложениями котиков по 200-300 грн. А в некоторых случаях - и по 100-150. Сами можете себе представить, какое там качество породы осталось (МФ, 24.06.2015);

- за-: СУК ваще прям засодержал площзаку, аж разорился (Н1, 04.08.2016); 
- от-: Какая связь? Ага, раз у нас предательская власть, давайте ее отмайданим. И провалимся в ад тет на 20 (А1, 08.09.2015);

- y-: Вне школь - они (занятия по основам веры. - Авт.) и так есть - хоть узанимайтесь факультативно (МФ, 23.04.2015).

Семантика отрицательного состояния / отрицательного результата действия иногда проявляется при использовании даже таких префиксов, которым в некоторых научных источниках приписывается лишь более широкое значение 'совершить (довести до результата)': ...заводчикам лучше самим кастрировать котят и сразу говорить об этом условии, чтобь у “бридеров" напрочь отбить желание, что-нибудь там набридить)) (МФ, 02.05.2012); (...) преступлений насовершали на цельй сериал (Россия 1, 16.11.2016).

Уточним, что посредством префиксов со значением 'совершить (довести до

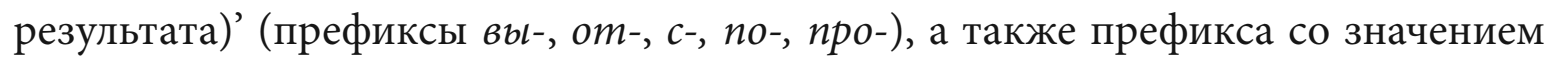
'довести до конца или до какого-н. предела' (префикс до-) регулярно создаются и стандартные глаголы, не связанные с выражением отрицательной оценочности. Заметного преобладания тех или иных моделей здесь не наблюдается: $У u x$ мамы по корпусу черный пигмент тоже заменился коричневым, хотя она до золота не доцвела (МАУ, 09.12.2012; о возрастных изменениях окраса у животного); Американиь обхаживают Китай. - Ну и что? Докуда они их дообхаживали? (Россия 1, 25.06.2017); И метрики у совладельцев забираю до кастрации. Откастрили? Отлично. Забирайте документы (МФ, 27.06.2015); Упс, по моему у меня глюкнул комп и продублировалась, вернее протроилась ботка (МФ, 01.02.2013); В нашей судьбе своеобразно проучаствовал (...) (Радио России, 03.11.2015); И вот мы уже видим Зембиру - нервную, переживаюшую, что ее проассоииируют с украинским флагом на кониерте (Культура, 08-14.04.2016, № 13); Как, говорите, фамилия? Правда, у нас работал? А у меня даже не сассоциировалось, что это может быть наш человек! (Собеседник, 2016, № 20). При этом обращает на себя внимание тот факт, что в форумном дискурсе префиксы с рассматриваемыми значениями периодически присоединяются к основам двувидовых глаголов, по сути дублируя их грамматическую семантику (семантику совершенного вида): Я согласна, что хочется сконкретизировать подарок.) (МФ, 15.11.2015); И даже больше, лично купил второго куна-кастрата в товарищи первому. Первого уже тоже скоро покастрируют (МФ, 20.03.2014). Появление плеоназмов в таких случаях, на наш взгляд, обусловливается комплексом факторов. С одной стороны, это желание говорящих наиболее точно и однозначно передать мысль, избежать инотолкований (которые в форумной коммуникации нередко порождают коммуникативные конфликты); с другой стороны - желание сделать речь более экспрессивной и/или непринужденной.

Аналогичным образом, видимо, можно объяснить и некоторые случаи заменительной префиксации, при которой новообразование создается путем замены префикса в исходном слове. В основном они связаны с отказом от использования префикса про-: и опять отиитирую интересную мысль (МФ, 11.01.2015) - подчеркивается интенсивность, тщательность действия (ср.: процитировать); Сцетировать не смогла. там текст большой (МФ, 03.01.2016) подчеркивается механизм цитирования - копирование (в данном случае можно 
говорить о создании нового слова по образцу глагола скопировать). Впрочем, отельные факты заменительной префиксации (Согласна:) сегодня отпробовали эту шаурму. Ну, не шедевр... прямо скажем (Н1, 06.10.2016); ср.: попробовали) в большей степени можно объяснить действием не семантического, а стилистического фактора, который более подробно будет рассмотрен ниже.

Прочие качественно-количественные и собственно качественные аспекты действий/состояний значительно реже обозначаются посредством неузуальных глагольных префиксатов. Соответствующие значения префиксов представлены немногочисленными (в ряде случаев - единичными) дериватами, например:

- 'повторно, заново, иногда по-новому, иначе совершить действие': Пользователь 1: У нее МОЗХ по другому заточен. Она машину не ВИДИТ. Пользователь 2: Вот если эту бабушку оштрабовать за первое нарушение рублей, эдак, на 500, за второе на 1000-2000 (хотя бъ), то я Вас уверяю, и моск у нее моментально перезаточится (А 1, 14.03.2017); Пороченко внимательно изучает эту встречу. Каждое слово слушает и переслушивает (Россия 1, 02.05.2017); - 'совершить в ответ': Да и в конце-то концов, мало у кого были свои участки лет 15-20 назад, держали все породы в квартирах, ещё и отругивались от тех, кто говорил, что собака должна жить в будке... (САОФ, 05.09.2009);

- 'уничтожить(ся), израсходовать(ся), употребить во что-н.': особенно она уважает куриный череп в продольном разрезе ... а череп этот практически с ее череп в габаритах.. и ничего..она его ухомячивает за пару минут.. (МФ, 19.07.2011) $)^{13}$

- 'упустить, пропустить что-н.': Украина проспала или промайданила, а Казахстан - традиии степи: вертеть головой на 260 градусов и далеко глядеть (СБ, 22.05.2014);

- 'добыть, получить что-н.': У нас тоже история о том, как муж вообще не терпел кошек) Пока у нас их две... А вторую(кунииу) я выныла.. (МФ, 23.10.2015).

Что касается пространственных значений, то степень их актуализации в современных деривационных процессах относительно невелика. Необходимость указать на какие-либо пространственные параметры действий/состояний значительно реже приводит к появлению новых префиксальных глаголов, чем необходимость обозначить те или иные качественно-количественные характеристики.

В форумном дискурсе пространственные оттенки префиксов, отличаясь некоторым разнообразием, легко объединяются в две группы:

1) перемещение в пространстве:

- 'достигнуть какого-н. места, прибыть (...) в какое-н. место': Пользователь 1: РОССИЯ БУДЕТ ЛЕЗТЬ. Пользователь 2: скажите, а куда она уже прилезла? У Вас имеются факты присутствия? (СБ, 30.04.2014);

13 В данном и предыдущем примерах добавление словообразовательных префиксов сочетается с заменой грамматического (видового) суффикса: ругаться $\rightarrow$ отругиваться, хомячить $\rightarrow$ ухомячивать. 
- 'направить сквозь что-н., через что-н.': они вдвоем в него (наполнитель для кошачьего туалета. - Авт.) ходят и он ооочень быстро стал пахнуть и прописываться (МАУ, 14.01.2012);

- 'довести (...) до какого-н. предела' (в данном случае - пространственного): Мне так было удобнее - в некоторых случаях пальчиком так подиепляла, морда поднималась, карие глаза печально косили в сторону жертвы, но не докашивали, и мы расходились (СБ, 30.07.2013);

- 'удалить(ся) с чего-н.': А полотенце-то какое яркое, красивое! Одно удовольствие будет котику его с вешалки стаскивать! (Мой постоянно сиарапьваem полотенчики на пол) (МФ, 16.12.2015);

- 'отделить(ся) от чего-н.': (...) месяи назад отгнил провод в монтажном блоке (A3, 25.04.2017);

2) охват пространства / расположенных на нем объектов:

- 'сплошь, полностью покрыть(ся) чем-н.': Пользователь 1: Чмокни Шанечку от меня в носик. Пользователь 2: Наташ, я ее всю учмокала... но мне кажется она не в восторге)))) (МФ, 21.06.2015);

- 'распространить действие (...) на много объектов': А сейчас - коньяку накатить, всех в охапку и спать. Бонсаи, Браху и Улиту можно не охапать, обойтись Лимохой и мужем (МФ, 05.02.2015);

- 'покрыть(ся), закрыть(ся) чем-л.': Взять, например, вонищу канашкой на Гордеевке, когда при строительстве метромоста че-то там расковыряли и годами(!) не заковьривали обратно (Н1, 29.04.2017).

Префикс за- с пространственной семантикой встречается и в медийных неузуальных глаголах: На форумах звучат призывы “заспамить" почты и сайты президента, правительства, природоохранной прокуратуры, комитета по правам человека... («Ленинская смена» 09.06.2016).

Временные аспекты действий/состояний еще реже, чем пространственные, обозначаются при помощи неузуальных глагольных префиксатов. Ввиду малочисленности таких единиц, соответствующие значения префиксов в рамках нашей выборки почти не поддаются систематизации. Приведем отдельные примеры:

- 'начать действие': Тем более же была мечта о черном куне))) Воплощаем, воплощаем, главное в прочессе не за мечтать еще и о красном)))) (МФ, 23.10.2015);

- 'окончить длившееся определенное время действие': A подарок к вам обязательно доберется...ми все отрадуемся, а у вас праздник продлится)) (МФ, 24.12.2015); Только не плачь. Соберись, отплачься (1-й канал, 09.06.2017) - во втором примере префикс от- выступает в составе префиксально-постфиксального форманта;

- 'совершить постепенно, совершить в течение некоторого времени': И сайдинг с дома поотведала, причлось кирпичом обкладьвать (СБ, 12.08.2010). Временные оттенки префиксов на форумах и в СМИ периодически реализуются в комплексе с количественно-качественными, например:

- 'совершить в течение некоторого времени (чаще недолго)': Помайданили, выьрали Ющза. Не понравилось то, что выбрали. Снова помайданили, выбра- 
ти Янука. Опять не то! (МФ); (...) московские фриганы. Так себя называют люди, использующие продукты, которье выбрасыьвают магазинь (...) в соисетях у них часто спрашивают, где в столице можно пофриганить, и просят указать конкретные адреса (Собеседник, 2016, № 22);

- 'совершить в течение какого-н. времени (чаще - длительного)': канеброн проеште курсом. 1 таб утром, одна вечером (МФ, 04.02.2015).

Сочетания значений префиксов в целом не редки в медийном и форумном дискурсах.

При создании и включении в текст глагольных префиксатов пользователи форумов и журналисты нередко обращаются к разнообразным стилистическим приемам.

В форумном дискурсе при образовании новых префиксальных глаголов достаточно популярным является использование разного рода несоответствий / контраста.

Многие из таких слов в форумном дискурсе обнаруживают черты оксюморона.

Как правило, пользователи форумов обыгрывают несоответствие количественных характеристик префикса и производящей основы: префикс (no-, noд-) указывает на малое количество чего-либо, а основа, соответственно, на большое. Конкретные типы семантических/смысловых несоответствий разнообразны:

- несоответствие по объему: пока что изенник пока не критичен совсем. но чет подообожрались они с этой осагой уже (А3, 29.03.2017; под- - 'совершить с незначительной интенсивностью', обожраться - 'объесться'14, т.е. 'съесть слишком много'15).

- несоответствие по степени интенсивности: Поддастали вы, честное слово. Разберитесь уже со своим заводчиком, прокляните его или простите/забудьme (МФ, 06.02.2016; под- - 'совершить с незначительной интенсивностью', достать - 'вызвать сильное раздражение'); всегда визуально боялась брать кур головы...видимо жара на меня подействовала и решила по-зверствовать (МФ, 12.07.2012; об использовании куриных голов в приготовлении еды для кошек; по- 'совершить с незначительной интенсивностью', зверствовать 'поступать крайне жестоко'16);

- несоответствие по степени значимости: И насчет "побежали покреститься" - я тоже среди таких. Нет, это точно не было из-за Ельцина, но крестилась я в 19-ть лет, сама. Потом решила подизучить во что же я верю и поняла, что мимо, что не верю (МФ, 09.11.2015; глагол изучить в языке, как известно, не имеет количественных сем, однако в контексте с его участием обозначается выяснение специфики мировоззрения, что предполагает высокую

14 Словарь русского языка: В 4-x т. Т. 2. Ред. А.П. Евгеньева. Москва: Русский язык, 1981, c. 552.

15 Там же, с. 578.

16 Словарь русского языка: В 4-х т. Т. 1. Ред. А.П. Евгеньева. Москва: Русский язык, 1981, c. 602 . 
степень социальной значимости и плохо коррелирует с префиксом, содержащим сему малого количества).

Медийный дискурс может обнаруживать сходные явления: Глава Чечни продолжает демонстрировать свое нарастающее всевластие. На минувшей неделе он всерьез подразогнал судебную власть республики... (Собеседник, 2016, № 17); см. также поднагнули (от жаргонного нагнуть 'заставить полностью подчиниться'), подзаглох.

Оксюмороны неколичественного характера в форумном дискурсе встречаются реже. Приведем пример игры на контрасте созидания-деструкции: (...) nри строительстве метромоста че-то там расковыряли и годами(!) не заковыривали обратно (H1, 29.04.2017) (за- - 'закрыть(ся) чем-л., то есть 'закопать', ковырять - 'раскапывать что-л. (... $\left.)^{\prime 17}\right)$.

Несколько реже сочетание префикса и основы дает близкий оксюморону троп - катахрезу. При реализации катахрезы - благодаря префиксу - действие, названное мотивирующим глаголом, начинает осмысливаться через категории, связь с которыми у него отсутствует. Возникающий при этом алогизм формирует заметную экспрессию: Я таки притащила себе МейнКуна!!! (...) Его хозяин взял котенком, с родословной, а потом внезапно подженился и дама с котом не поладили... (САОФ, 21.07.2011). Так, действие, называемое глаголом жениться, не имеет степеней интенсивности, в то время как префикс под- со значением 'совершить с незначительной интенсивностью действие, названное мотивирующим глаголом', указывает на одну из них.

Стилистический контраст в форумном дискурсе, как правило, базируется на дихотомии «книжное - разговорное»: Это ж сколько надо времени чтобь с каждым слово молвить, на поводок взять, в иентр города сгонять - посоииализироваться, еду правильную приготовить, раздать, расчесать, ощупать и в боруме побузить! (СБ, 16.03.2012). В приведенном примере разговорный префикс присоединяется к книжной основе (формируя при этом представление о низкой ценности действий оппонента). Возможно и обратное сочетание «книжный префикс - разговорная основа». О коте: Фадей изволилсъ откакать! (МФ, 22.05.2012). Префикс om- со значением окончания длительного действия не является собственно книжным (см., например, отивести), однако многие слова рассматриваемого словообразовательного типа заметно тяготеют к художественному стилю (отлюбить, отстрадать, отбушевать, отшуметь и др.), что и позволяет реализоваться рассматриваемому приему.

Определенную экспрессию дает использование в узком контексте антонимичных префиксов (при этом неузуальным, как правило, является только одно из слов, включающих такие морфемы): Вот полностью согласна с тем что аварийку включать стесняться не нужно! Лучше перестраховаться, чем недостраховаться (A1, 20.04.2012) (ср. также в медийном дискурсе: передобавила - недоубавила). Значительно большую функциональную нагрузку имеют дериваты, у которых к языковой игре подключаются производящие основы: Енотик очень хорошая машина, но дизайнерь явно перемудрили.... или недомудрили

17 Словарь русского языка: В 4-х т. Т. 2. Ред. А.П. Евгеньева. Москва: Русский язык, 1981, с. 66. 
(A1, 02.10.2008). В приведенном примере происходит каламбурное обыгрывание основы мудрить: в слове перемудрили она имеет узуальное отрицательное значение '(...) искать более сложные решения чего-л., пренебрегая простыми и ясными путями'18, а в слове недомудрили - контекстуальное положительное 'тщательно обдумывать, вдумываться'. Это позволяется представить неопределенность, незаконченность внешнего вида автомобиля и за счет комического снижения выразить отрицательное отношение к данному факту. См. также пример выше: расковыряли и годами(!) не заковыривали обратно (Н1, 29.04.2017).

Наконец, рассмотрим оценочный контраст, а именно несоответствие оценки, закрепленной за словообразовательной единицей, и фактической оценки обозначаемого явления. В форумном дискурсе чаще наблюдается сочетание «отрицательная словообразовательная модель - положительная оценка явления»: Kот, который “да хоть зацалуй в носопьрку, хочешь - на еще раз!, хоть заобжамкай, хоть запереобсюсюкайся!, только гладь, обнимай, держи на ручках! я на всё ради этого готов!”)) (МФ, 18.02.2015); НО если кошь пришла ласкаться к дочери.... истопчет, избодает, умурлькает... (МФ, 29.01.2015).

Как наглядно демонстрируют примеры, в форумном дискурсе контрастные дериваты используются прежде всего для создания комизма в разных его проявлениях - от легкой шутки до резкого сарказма. При этом закрепленности стилистических эффектов за определенными морфемами / моделями не наблюдается.

Амплификация (или, иначе, нагнетение) используется в обоих типах дискурса. Стилистический прием представлен в двух основных вариантах.

Очень экспрессивным является нанизывание префиксов в пределах одного слова: Понаговорились ? Понаругались ? A теперь батьку послушаем (A1, 18.08.2012); Давно брожу по порталу. Исперечитала вдоль и поперек (МП, 12.03.2009). Экспрессия значительно усиливается, если к производящей основе одновременно присоединяется несколько префиксов в качестве единого, сложного форманта: Даже не попереприпоминаю каких я только перлов не попереслушала (МФ, 31.07.2013); см. также: хоть заобжамкай, хоть запереобсюсюкайся (МФ, 18.02.2015); Пиар-услуги - это когда за определенную сумму можно глаза «приподзакрыть»... (Селедка, 2016, № 2).

Несколько меньшей экспрессией (по причине относительной типичности) обладает нанизывание префиксальных глаголов, образованных по одной модели: я с ним недоговорил, недоходил, недосмеялся, недохохотал... (НТВ, 05.11.2016); Он ее расбантазировал, расширил, развспомнил (Культура, 22.10.2016); (...) и поляков подбодрить, и немцев подохладить (Россия 1, 09.07.2017); Какая ты добрая. Я бы уже обгудел, обморгал обприжимал (А1, 17.07.2012); Пахнет (...) сильновато сперва, как насыпешь новый. Потом или он подвыветривается, или я подпринюхиваюсь (МАУ, 21.08.2012).

Яркие стилистические эффекты дает образование глаголов по конкретному образиу.

Часть слов создается по образцу глаголов с синонимичными основами. Некоторые из таких единиц работают преимущественно как средства усиления

18 Там же, c. 308. 
экспрессии - за счет своей нетипичности, отступления от нормы (образца): Хохотала так, что мой весельй морд пришел, сочувственно посмотрел хитрожопыми глазами - чего, прихворала? (МФ, 16.03.2016), ср.: приболела. Прочие глаголы заимствуют и активно транслируют оценочность слова-образца (или сочетания, частью которого оно является): не надоело поднюхивать? (H1, 19.02.2015) - реакция на регулярные сообщения одного из пользователей форума о запахе, идущем с очистных сооружений, ср.: подслушивать/подсматривать; Потому как одна будет тикировать, тикировать, да не вытикирует (МАУ, 30.12.2012) - о неудачной попытке вывести кошек тикированного окраса, ср. устойчивое сочетание - скороговорку лавирует, лавирует, да не вылавирует; Не скажу, что у пиканты расход бензина меньше.. (...) пока что больше мотьки 0,8л кушает.. я бы сказала обкушавает (А1, 07.09.2011), ср.: объедает.

Отмечается также образование новых глаголов по образцу слов той же тематической группы:

- издавать звуки, продуцировать речь: (...) кот мурчал очень тихо, слегка вибрации ощущались. правда сегодня удалось его размуриать, пока он дремал!)) затарахтел как трактор)) (МФ, 02.03.2015); ср.: разговорить;

- издавать звуки, петь: Я с некоторых пор запала на эту песню и пела ее им, а у Декса урчалка очень хорошо в такт этой песни попадает, а может научился ее подуркивать... (...) Мерик ушел спать на мою ногу и уже Шаня под моим носом тоже что-то науркивала, но я уже была в полудреме (МФ, 02.06.2015); ср.: подпевать, напевать;

- принимать пищу: Асу присоединилась и отлакала у меня красного сухого вина. Вот это да (МФ, 04.09.2009).

Наконец, как стилистическое средство (средство создания экспрессии) можно отметить использование в форумном дискурсе неузуальных словообразовательных моделей, однако встречается оно достаточно редко: Да, любить Родину так, как любит ребенок мать-алкоголичку (со всеми вытекающими) это сильно. Это же насколько нужно быть.... Нет.... Небыть.... Именно такой глагол. Несуществующий (МФ, 18.10.2015); с чего вы в своё время так анти-активничали в моей ПРОБЛЕМЕ? (СБ, 28.02.2011).

В медийном дискурсе глагольные префиксаты включаются в процессы графодеривации. В частности, префиксы используются в составе дериватов с использованием прописных букв (капитализация): скинуть по полной (о скидках на товары. - Авт.) (Антенна-Телесемь, 25-31.01.2016, № 3).

Как показало исследование, пользователи конкретных форумов в разной степени прибегают к глагольной префиксации. Наибольшее количество примеров фиксируется на форумах любителей домашних животных (и прежде всего на Форуме о мейнкунах - http://mainecoon-forum.ru). На форумах о недвижимости и форумах любителей речных круизов глагольная префиксация представлена в меньшей степени. При этом в целом для форумного дискурса рассматриваемый способ образования можно признать достаточно типичным. В текстах СМИ глагольные неодериваты отмечаются несколько реже, чем на страницах форумов, однако их типичность для медийного дискурса также не вызывает сомнений. 
В форумном и медийном дискурсах задействуются не все средства, представленные в словообразовательной системе современного русского языка. При этом у используемых единиц диапазон значений оказывается несколько шире, чем в традиционно описываемой системе узуальных словообразовательных средств. Продуктивность конкретных префиксов в рассмотренных видах дискурса может различаться; но в целом и пользователи форумов, и журналисты чаще делают выбор в пользу единиц с количественно-качественными оттенками, которые в большей степени позволяют выразить субъективное (нередко негативное) отношение к конкретному действию и ситуации в целом.

Глагольные новообразования реализуют разнообразные функции. Они позволяют не только дать оценку обозначаемым реалиям (действиям, процессам), но и конкретизировать смысл (в частности, при добавлении префиксов к двувидовым глаголам); сделать сообщение более эмоциональным, придать ему интересную, легкую для восприятия форму; реализовать креативный потенциал личности.

Таким образом, исследование неузуальных глагольных префиксатов в форумном и медийном дискурсах позволяет выявить специфику отображения и оценки актуальных для носителей языка фрагментов действительности.

\section{Литература}

Земская Е.А. Активные проиессы современного словопроизводства. [В:] Русский язык конияа ХХ столетия (1985-1995). Москва: Языки русской культуры, 1996, с. 90-141.

Коряковцева Е.И. Очерки о языке современных славянских СМИ (семантико-словообразовательный и тингвокультурологический аспекты). Siedlce: Uniwersytet Przyrodniczo-Humanistyczny w Siedlcach, 2016.

Кузьмина Е.Б. Идеологический прагматический компонент семантики слов русского языка (лексикографический аспект). «Studia Rossica Gedanensia» 2016, nr 3, c. 159-168.

Русская грамматика. Т. 2. Москва: Наука, 1980.

Словарь русского языка: В 4-х т. Ред. А.П. Евгеньева. Москва: Русский язык, 1981-1984. 